Lepr Rev (1984) 54, 77-78

SPECIAL ARTICLE

\title{
Acworth Leprosy Hospital, Bombay
}

\author{
G W ACWORTH \\ Upper Hill House, 28 St Anne's Road, Malvern, Worcestershire \\ WR14 4RG
}

Harry Acworth, a principal founder of the Acworth Leprosy Hospital, joined the Indian Civil Service in 1870 aged 21. He was educated at Brighton College and Oxford and qualified as a barrister before going to India, where he served 25 years in the Bombay Presidency (Maharashtra and Gujarat), ending his career, 1890-95, as Municipal Commissioner of Bombay. On retirement to Malvern, he got to know and to play golf with Elgar and he was also active in local government and church aff airs until deafness cut him off more and more from the world. My clearest memory of him during the last years is the clatter of his machine as he typed Braille books for the blind.

The above is a brief sketch of the man whose name still stands over the gateway of the Acworth Leprosy Hospital in Bombay, which he did so much to establish.

In June 1890, a Lady Thompson wrote to the Times of India drawing attention to the desperate state of lepers on the streets of Bombay and pleaded for a home to be built for them. This led to a public meeting at which the idea was not too well received and a mere Rs 12,000 were raised. It was then that Acworth took matters in hand, risking, so the Times thought, his reputation as the new Municipal Commissioner (with the distinct chance of a fiasco).

He undertook 'immense' labours himself, personally visiting and collecting donations from shopkeepers until, in February 1891, he was able to report to a 'jubilant' meeting his 'triumph' in raising Rs 73,000. By then he had already established 200 leprosy patients in the 'model' Matunga Asylum, which was officially opened on 7 November 1890.

This was the first time in India that the principle of compulsory restraint was applied to the victims of leprosy. The laws, first of Bengal and then of the Government of India itself, were based on the experience of Matunga. The reduction of vagrancy and of infection on the streets was coupled with a benign project of genuine welfare benefit. That the compulsory element was not onerous is shown by the fact that volunteers came from far and wide to the Asylum. Indeed, some cottages were soon built for paying patients. Running costs were covered jointly by the Government and the City Corporation at a monthly rate of Rs 10 per patient.

The title of the institution changed as it grew and as its functions developed: 1904, Acworth Leper Asylum with 351 beds; 1935, Acworth Leprosy Home with 399 beds; 1956, Acworth Leprosy Hospital with 500 beds.

In 1911 a Board of Management of 20 members under the presidency of the Municipal Commissioner was established under the Leprosy Act of 1898, but it was not until 1929 that the Board appointed a Medical Advisory Committee. However, the Asylum still remained just that, providing domiciliary in-patient treatment and sheltered workshops for its few hundred inmates.

At last, in 1935, out-patient treatment started, and in 1939 the Superintendent began training 
courses for the staff of Government and Municipal Dispensaries, thus extending more widely the possibilities of early detection and treatment. This led, in 1942, to the appointment of the first Health Visitors to follow-up patients and their contacts.

Over the years the buildings had been constantly extended to accommodate more patients and to expand the facilities. By 1939 there was a laboratory and lecture hall, and in 1950 an operating theatre was built. In 1963 a Craft Training Centre and Sheltered Workshop were provided by the Tata Trusts and some 10 years later the physiotherapy block was opened.

Acworth first used promine for treatment in 1946 and dapsone 5 years later. The latter drug was first tried out there in 1956 for prophylactic treatment by para-medical workers.

Meanwhile, thanks to the efforts of Dr Wardekar, in 1955 the Greater Bombay Leprosy Control Scheme (GBLC) was started with 5 clinics for Survey, Education and Treatment (SET). This number doubled in the next 15 years. The Superintendent of Acworth supervised the medical work of the Scheme and in 1959 its management was transferred from the Corporation to the Board of the Acworth Leprosy Hospital.

From 1950 to 1961 the Indian Council of Medical Research had conducted an inquiry into leprosy there. Subsequently, the hospital set up its own Research Unit. It is surprising to note that it was not until 1956 that leprosy training was included in the MBBS degree course as well as in the Ayurvedic Faculty. These were both undertaken by Acworth.

In 1964 and 1965, the Hospital received an award for the voluntary institution doing the best leprosy control work.

My wife and I were able to visit the Hospital several times in the course of our travels for Oxfam, most notably in 1969 for the celebration of Gandhi's centenary. In company with the Municipal Commissioner, we unveiled and garlanded the bust of Harry Acworth, for which his friends had subscribed 79 years before, and we planted commemorative shrubs.

It may give some idea of the scale of operations to record that in 1969 Acworth and the GBLC Scheme had then, annually: a turnover of Rs 10 lakhs; 91 staff; 15,800 old patients; 5700 new patients; 5500 social workers' interviews; 60 lectures and seminars; 12 exhibitions; 337 physiotherapy patients; 29 plastic and reconstructuve surgical operations; 7800 house visits; 7 research projects; 682 in-patients and training in and production of carpentry, weaving, tailoring, leather and vegetable production. They told us they had 60,000 patients on their books.

A postcript. In 1898 Harry Acworth read a paper on 'Leprosy in India' at the Imperial Institute, London. Dr Armauer Hansen characterized it as the ablest statement of the case which he had ever heard from a non-medical man. 